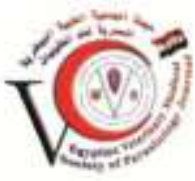

\title{
Parasitological Prevalence of Cryptosporidium infection in calves, chickens and human in Behera province
}

Bessat M.N. ${ }^{1}$ *, Elaadli
H.F. ${ }^{2}$, and Labn, N.E.
${ }^{1}$ Department
Parasitology,
${ }^{2}$ Department of
Hygiene and
and
Faculty of
Medicine,
University
Abis 10, Alexandria
Egypt Alexandria,
Post Code: 21944
${ }^{*}$ Author of correspondence:
mohamed.bessat@alexu.edu.eg

\begin{abstract}
:
Cryptosporidium is a cosmopolitan intestinal protozoan parasite that belongs to the phylum Apicomplexa and infects a broad range of vertebrate hosts including livestock, human and birds. This current study was aimed to investigate the prevalence of Cryptosporidium spp. infection in young calves, human and chickens, in five districts covering five different geographical locations of the Behera province. In doing this, a total number of 310 faecal samples from calves $(n=148)$, human being $(n=112)$ and chicken $(n=50)$ were collected, stained using the modified Ziehl-Neelsen staining method, and were examined microscopically for Cryptosporidium spp. oocysts. Correlations between prevalence rates and related parameters such as species, age, gender and faecal consistencies were also analyzed. Results indicated that $43.2 \%, 16.1 \%$ and $6 \%$, of calves, human and chicken, were found infected with Cryptosporidium spp., respectively. Statistically significant variable rates of infection were also detected across six surveyed districts of the Behera governorate, with the notable absence of infection from chicken in Abo Hummus and Rahmaneyah districts. Statistically significant variable rates of infection were also characterized in calves when species, age, sex, and faecal consistency were analyzed; buffalo $>4$ weeks calves, male and calves with formed faeces have higher infection rates than their counterparts of cattle $<4$ weeks, female, and calves with semi-formed and diarrheic faeces. Slightly contrast data were obtained from human; younger ( $<15$ years), female, and diarrheic individuals have higher infection rates than their compared counterparts. Detection of Cryptosporidium spp. in the livestock and chicken living in close proximity to human population necessitates better surveillance and control measures to protect vulnerable animal and human populations.
\end{abstract}

Key words: Cryptosporidium; calves; human; chicken; modified ZiehlNeelsen staining

\section{Introduction}

Cryptosporidium is common enteric parasite that belongs to phylum Apicomplexa. It is a coccidian protozoan infects a wide range of vertebrate animal hosts, human and birds (Fayer, 2010; Plutzer and Karanis, 2009 and Ryan et al., 2014).
In cattle, infection with Cryptosporidium is prevalent in the preweaned calves, resulting in a clinical disease with the potential of zoonotic transmission to human contacts, particularly in the case of $C$. parvum (Feng et al., 2007 and Zhang et al., 2013). In humans, cryptosporidiosis results 
in many diarrheal outbreaks globally and may be acquired through direct contact with infected person or animals, and indirectly through consumption of food contaminated with oocysts (Chalmers and Davies, 2010 and Xiao, 2010). Water also represents a major source of infection as Cryptosporidium oocyst is considered resistant to chlorine used in water disinfection (Baldursson and Karanis, 2011 and Karanis et al., 2007a). Cryptosporidium is estimated to be the second leading etiological infectious agent of diarrhea and death in infants in poor countries after rotavirus infection (Kotloff et al., 2013 and Striepen, 2013). In immunocompetent persons, the clinical picture of the disease is usually slight fever, mild abdominal discomfort and selflimiting watery diarrhea, but in immunodeficient humans, however, the infection is frequently chronic with persistent diarrhea, malabsorption and may lead to death, especially in the Acquired Immuno Deficiency Syndrome (AIDS) and cancer patients (Wumba et al., 2015).

On the other hand, birds are infected with a number of Cryptosporidium species. Chicken, turkeys and aquatic birds are considered as a reservoir for transmission to human particularly in the case of Cryptosporidium meleagridis (Bomfim et al., 2013).

Cryptosporidium infection in farm animals and humans is detected through several methods that can be broadly categorized under microscopy, serology, and the molecular-based diagnostic methods (Khurana and Chaudhary, 2018). Despite advances that have been made in developing serological and molecular tools of Cryptosporidium diagnosis such as ELISA, IFAT, PCRRFLP, the microscopical observation of oocysts in the stool/faecal samples using acid fast stains like the modified ZiehlNeelsen stain and Kinyoun stain remains the most conventional and the goldstandard technique of cryptosporidiosis diagnosis (Clarke and McIntyre, 2001 and Ma and Soave, 1983).

In Egypt, the intensive and semiintensive farming practices of the cattle livestock in the highly dense-populated delta region constitute a major source of infection dissemination (El-Saharty et al., 2005). Similarly, keeping the livestock in close proximity to human and other animal species and birds is major zoonosis concerns, making the monitoring of occurrence of Cryptosporidium in human and animals a priority from the perspective of the veterinary and public health importance. Thus, this study was initiated with the aim of surveying the occurrence of Cryptosporidium in calves, human, and chicken, by examining faecal/stool samples that were collected from overlapping geographical areas located at the Behiera province. Correlation between different factors, such as species, age, sex and the faecal consistency, with that of infection prevalence rates was also assessed.

\section{Material and Methods Study locations:}

The study was conducted in the municipalities of Behera province, located in the West of the Delta region of Egypt (Coordinates: $30.61^{\circ} \mathrm{N} 30.43^{\circ} \mathrm{E}$ ). Five locations representing five districts were sampled during the current study, covering the South, West, North and the East of the province. This namely included Delingat, Shubrakhit, Rahmania, Abou Hommos and Hosh Eisa (Fig.1).

Animals and human being and sample collection:

During the period from January to October (2019), a total of 310 fresh faecal samples were collected from calves, human and chickens, respectively. These included 148 pre-weaned calves of ages ranged from one week to up to 2 months, different sexes of cattle versus buffaloes, and of different faecal consistency; diarrhoea, semi formed and formed. For calves; faecal samples were obtained 
directly from the rectum of each individual animal. For human; stool specimens were collected from 112 individuals attending various health units (hospitals, rural clinics and private diagnostic laboratories), as these individuals were of different ages, gender and stool consistency. For chickens; pools of faecal droppings were collected from 50 chicken flocks aged over 90 days (the minimum number is 10 birds /flock) from areas that overlapped with calves and human being.

\section{Collection and identification of oocysts:}

Faecal specimens were collected in plastic cups, immediately transported in ice -cooled to the laboratory of Parasitology Department, Faculty of Veterinary Medicine, Alexandria University. If faecal specimens unable to be examined directly, the specimens were kept with $2.5 \%$ potassium dichromate solution in refrigerator at $4{ }^{\circ} \mathrm{C}$ according to Karanis et al. ( 2007b) and Ma et al. (2014). Direct smears were prepared from faecal specimens and processed for microscopical examination. Also, the oocysts were identified by acid fast staining by using modified Ziehl-Neelsen stain according to (OIE, 2008) for more clarify and identifications. Briefly, about $1 \mathrm{gm}$ of faeces were transferred to a clean microscopic slide, thin smear was done with another glass slide spreader. Then the smears were dried in the air or in hot air oven under 40-50 $\mathrm{C}$ and fixed with few drops of absolute methanol for 5 minutes. The slides were then stained with carbol fuchsin for $15 \mathrm{~min}$, and the excess stain was washed with tap water before they were decolorized with $1 \%$ acid alcohol for 15 seconds. The slides were washed again with tap water before counterstained with $0.4 \%$ methylene blue for $1 \mathrm{~min}$, and before finally rinsed with tap water and air dried. Cryptosporidium oocysts were detected by examining the stained smears under the 40X and 100X-oil immersion objectives of the optical light microscope (Optika, Italy).

\section{Statistical analysis:}

The potential statistical correlation between prevalence and various parameters (animal host species and the geographical locations), and the correlation between the detection rates within the same host species in relation to parameters of age group, sex and fecal consistency was done. This was done by using the Chi square test and the Fisher's test included in the SPPS statistical package. Statistical significance was proved when $\mathrm{p}$-value was $<0.05$.

\section{Result}

Microscopy-based examination of faecal smears stained with the modified Ziehl-Neelsen stain revealed the characteristic diagnostic stages of Cryptosporidium as acid fast-stained oocysts on a blue background (Fig. 2). The overall prevalence rates of Cryptosporidium spp. in calves, human being and chickens were $43.2 \%, 16.1 \%$ and 6\%, respectively (Table 1).

With except of chickens, infection with cryptosporidium was recorded from calves and humans in all the five districts assayed, albeit with no statistical significance $(\mathrm{P}=0.431)$ of detection rates between different districts (Table 2). When placed in comparison, Hosh Eisa was recorded with the highest rate of positive calves $(57.9 \%)$, but with the lowest rate of human with cryptosporidium infection (3.1\%). This is completely opposed to Rahmaneyah, with the highest and lowest rates were for human and calves, respectively (Table 2 ).

Cryptosporidium infection was detected in calves of different species, age, sex, and the faecal consistency status (Table 3). With except of species, statistically significant differences were recorded with age $(\mathrm{P}=0.016)$, sex $(\mathrm{P}=0.023)$ and faecal consistencies $(\mathrm{P}=0.047)$. With species, 28 out of 80 (35\%) of cattle calves and 36 out of 68 $(52.9 \%)$ of buffalo calves, were recorded positive with cryptosporidium, albeit with 
no statistical significance $(\mathrm{P}=0.112)$ of the difference between the two species. Older calves (> 4 weeks) have had a higher statistically significant incidence rate of cryptosporidium $(44.4 \%)$ than younger calves $(<4$ weeks) rate $(40.4 \%)$. Results also revealed that $45.5 \%$ (50 of 110 ) of male and $36.8 \%$ (14 of 38) of female calves were positive for Cryptosporidium (Table 3). Cryptosporidium was detected in calves with formed, semi formed and watery faecal conditions by infection rates $47.9 \%, 31.6 \%$ and $42.9 \%$, respectively.

Similar to calves, variable detection rates for cryptosporidium were recorded from human of different age groups, gender and stool consistencies, albeit in a non-statistically significant variations (Table 4). Cryptosporidium infection was detected in $17.2 \%$ (10 of 58) and 14.8\% (8 of 54) in age groups of $<15$ years and $>15$ years, respectively. From the gender perspective, $11.5 \%$ (6 of 52) of male persons and 20\% (12 of 60) of females were identified as positive for Cryptosporidium. Similarly, diarrheic human persons registered a higher detection rate $(35.7 \%)$ than those with formed $(10 \%)$ and semi-formed $(9.1 \%)$ stools (Table 4).
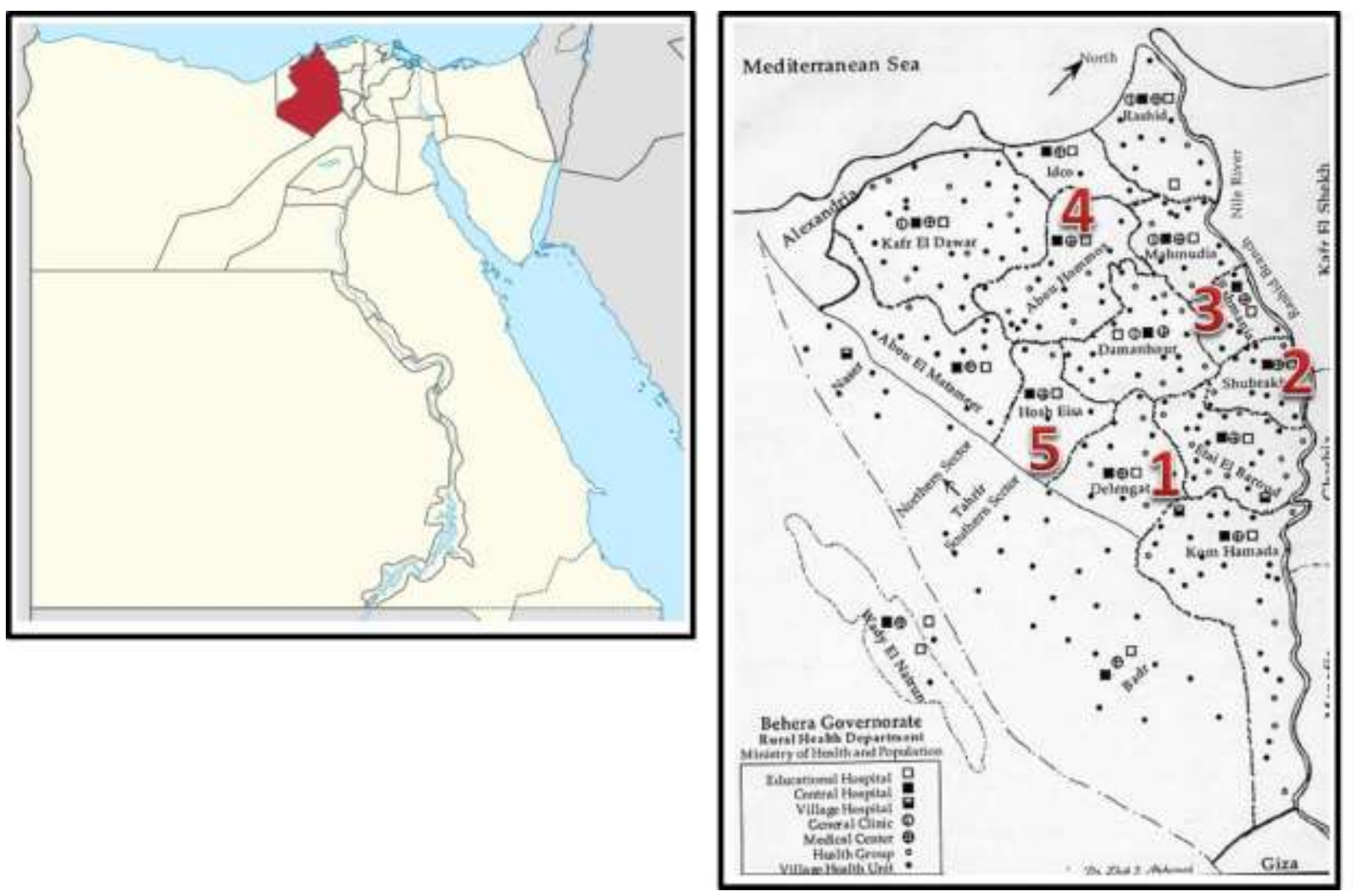

Fig. 1: A map showing the location-sampling sites for the current study in Behera governorate.

(1) Delingat, (2) Shubrakhit, (3) Rahmania, (4) Abou Hommos, and (5) Hosh Eisa 


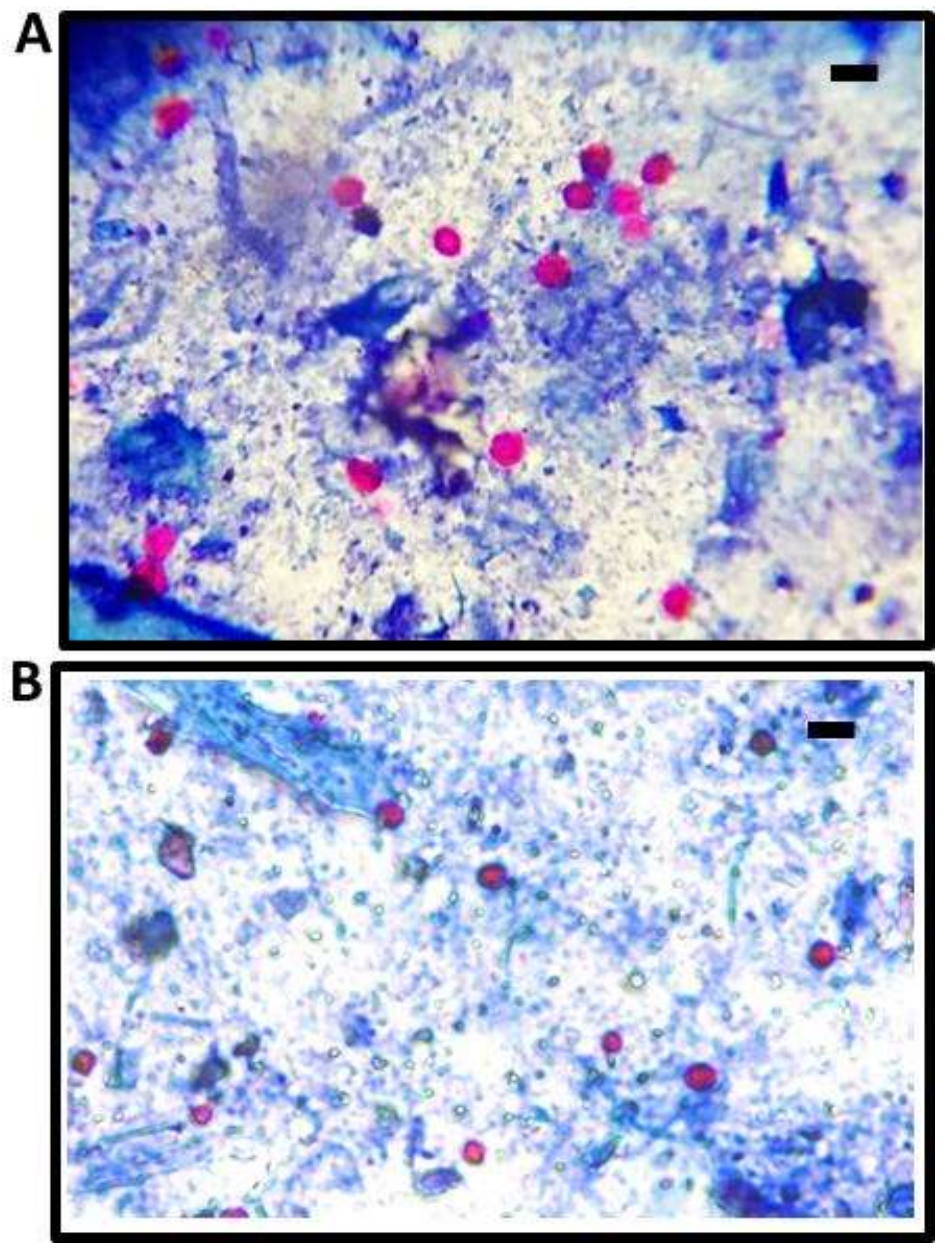

Fig. 2: Detection of oocysts of Cryptosporidium spp. in the faecal smears that were processed using the modified Ziehl-Neelsen staining. A) Mammals (calves, human being); B) Chickens. Microscope magnification of $40 \mathrm{X}$. The scale bar: $5 \mu \mathrm{M}$.

Table 1: Prevalence of Cryptosporidium spp. in the faecal/stool smears of calves, humans and chicken

\begin{tabular}{|l|c|c|c|c|c|}
\hline \multicolumn{1}{|c|}{ Host } & $\begin{array}{c}\text { Number of examined } \\
\text { samples }\end{array}$ & Positive & $\begin{array}{c}\text { Percentage } \\
(\boldsymbol{\%})\end{array}$ & $\mathbf{9 5 \%}$ CI & p-Value \\
\cline { 1 - 4 } Calves & 148 & 64 & 43.2 & $2.5-17.2$ & \multirow{2}{*}{0.139} \\
\cline { 1 - 3 } Human & 112 & 18 & 16.1 & $2.3-17.8$ & \\
\hline Chicken & 50 (pools) & 3 & 6 & $2.3-19.9$ & \\
\hline
\end{tabular}


Table 2: Prevalence of Cryptosporidium spp. in calves, humans and chicken according to the geographical locations of the sampling sites

\begin{tabular}{|c|c|c|c|c|c|c|c|}
\hline \multirow[t]{2}{*}{ Region } & \multicolumn{2}{|c|}{ Calf } & \multicolumn{2}{|c|}{ Human } & \multicolumn{2}{|c|}{ Chicken } & \multirow{2}{*}{$\begin{array}{c}\text { p- } \\
\text { Value }\end{array}$} \\
\hline & $\begin{array}{c}\text { Examined } \\
\text { samples } \\
\text { (n) }\end{array}$ & $\begin{array}{c}\text { No. } \\
\text { Positive } \\
\text { samples } \\
(\%)\end{array}$ & $\begin{array}{l}\text { Examined } \\
\text { samples } \\
\text { (n) }\end{array}$ & $\begin{array}{c}\text { No. } \\
\text { Positive } \\
\text { samples } \\
(\%)\end{array}$ & $\begin{array}{c}\text { Examined } \\
\text { samples } \\
\text { (pools) } \\
\text { (n) }\end{array}$ & $\begin{array}{c}\text { No. } \\
\text { Positive } \\
\text { samples } \\
(\%)\end{array}$ & \\
\hline Delengat & 26 & $\begin{array}{c}9 \\
(34.6)\end{array}$ & 18 & $\begin{array}{c}4 \\
(22.2)\end{array}$ & 12 & $\begin{array}{c}1 \\
(8.3)\end{array}$ & \multirow{5}{*}{$\mathrm{P}=0.431$} \\
\hline Shubrakhit & 38 & $\begin{array}{c}13 \\
(34.2)\end{array}$ & 14 & $\begin{array}{c}2 \\
(14.3)\end{array}$ & 9 & $\begin{array}{c}1 \\
(11.1)\end{array}$ & \\
\hline $\begin{array}{l}\text { Abu } \\
\text { Hummus }\end{array}$ & 19 & $\begin{array}{c}11 \\
(57.9)\end{array}$ & 21 & $\begin{array}{c}5 \\
(23.8) \\
\end{array}$ & 6 & $\begin{array}{l}\text { Zero } \\
(0)\end{array}$ & \\
\hline Hosh Eisa & 42 & $\begin{array}{c}24 \\
(57.1)\end{array}$ & 32 & $\begin{array}{c}1 \\
(3.1)\end{array}$ & 16 & $\begin{array}{c}1 \\
(6.2)\end{array}$ & \\
\hline Rahmaneyah & 23 & $\begin{array}{c}7 \\
(30.4)\end{array}$ & 27 & $\begin{array}{c}6 \\
(22.2)\end{array}$ & 7 & $\begin{array}{c}\text { Zero } \\
(0)\end{array}$ & \\
\hline
\end{tabular}

Table 3: Detection rates of Cryptosporidium spp. in calves, and its relation to parameters of age, sex and fecal consistency

\begin{tabular}{|c|c|c|c|c|}
\hline Groups & $\begin{array}{c}\text { No. of } \\
\text { examined }\end{array}$ & $\begin{array}{c}\text { No. of positive } \\
(\%)\end{array}$ & $95 \% \mathrm{CI}$ & p-Value \\
\hline \multicolumn{4}{|l|}{ Species } & \multirow{3}{*}{$\mathrm{P}=0.112$} \\
\hline Cattle & 80 & $\begin{array}{c}28 \\
(35)\end{array}$ & $10.3-33.5$ & \\
\hline Buffalo & 68 & $\begin{array}{c}36 \\
(52.9)\end{array}$ & $9.9-38.7$ & \\
\hline \multicolumn{4}{|c|}{ Age (weeks) } & \\
\hline $1-4$ & 58 & $\begin{array}{c}24 \\
(41.4)\end{array}$ & 3.6-13.7 & \multirow{2}{*}{$\mathrm{P}=0.016$} \\
\hline $4-8$ & 90 & $\begin{array}{c}40 \\
(44.4) \\
\end{array}$ & $5.0-27.7$ & \\
\hline \multicolumn{4}{|l|}{ Sex } & \\
\hline Male & 110 & $\begin{array}{c}50 \\
(45.5) \\
\end{array}$ & $7.2-22.5$ & \multirow{2}{*}{$\mathrm{P}=0.023$} \\
\hline Female & 38 & $\begin{array}{c}14 \\
(36.8)\end{array}$ & $4.2-9.4$ & \\
\hline \multicolumn{4}{|c|}{ Fecal consistency } & \\
\hline Diarrhea & 14 & $\begin{array}{c}6 \\
(42.9)\end{array}$ & $5.3-41.2$ & \multirow{3}{*}{$\mathrm{P}=0.047$} \\
\hline $\begin{array}{l}\text { Semi- } \\
\text { Formed }\end{array}$ & 38 & $\begin{array}{c}12 \\
(31.6)\end{array}$ & $6.2-29.2$ & \\
\hline Formed & 96 & $\begin{array}{c}46 \\
(47.9)\end{array}$ & $9.0-7.0$ & \\
\hline
\end{tabular}


Table 4: Detection rates of Cryptosporidium spp. in the human and its relation to parameters of age, gender and fecal consistency

\begin{tabular}{|c|c|c|c|c|}
\hline Groups & $\begin{array}{c}\text { No. of } \\
\text { examined }\end{array}$ & $\begin{array}{c}\text { No. of positive } \\
(\%)\end{array}$ & $95 \% \mathrm{CI}$ & p-Value \\
\hline \multicolumn{4}{|c|}{ Age (years) } & \multirow{3}{*}{$\mathrm{P}=0.126$} \\
\hline$<15$ & 58 & $\begin{array}{c}10 \\
(17.2)\end{array}$ & $3.0-13.6$ & \\
\hline$>15$ & 54 & $\begin{array}{c}8 \\
(14.8)\end{array}$ & $3.2-11.5$ & \\
\hline \multicolumn{4}{|l|}{ Gender } & \multirow{3}{*}{$\mathrm{P}=0.127$} \\
\hline Male & 52 & $\begin{array}{c}6 \\
(11.5) \\
\end{array}$ & $3.3-16.0$ & \\
\hline Female & 60 & $\begin{array}{c}12 \\
(20)\end{array}$ & $3.4-14.7$ & \\
\hline \multicolumn{4}{|c|}{ Stool consistency } & \multirow{4}{*}{$\mathrm{P}=0.077$} \\
\hline Diarrhea & 28 & $\begin{array}{c}10 \\
(35.7)\end{array}$ & $5.7-42.2$ & \\
\hline $\begin{array}{l}\text { Semi- } \\
\text { formed }\end{array}$ & 44 & $\begin{array}{c}4 \\
(9.1)\end{array}$ & $5.4-44.6$ & \\
\hline Formed & 40 & $\begin{array}{c}4 \\
(10)\end{array}$ & $5.5-43.8$ & \\
\hline
\end{tabular}

\section{Discussion}

Comparing the current results with that previously recorded from calves in Egypt; revealed a higher rate $(43.2 \%)$ than previously recorded rates of $30.2 \%$, $34.1 \%, \quad 30.4 \%$ and $9.2 \%$ of Cryptosporidium infection in calves in different Egyptian governorates (Amer et al., 2010; El-Seify et al., 2012; Ghoneim et al., 2017 and Shaaban et al., 2018). As well as the current study revealed Cryptosporidium infection in human was $16.1 \%$ and was lower than that found by (Ghoneim et al., 2017) who reported infection rate of $27 \%$, but it was higher than (Helmy et al., 2013) who recorded $6.7 \%$ prevalence rate.

Only three districts out of five were presented with positive detection rates of cryptosporidium oocysts in chicken samples, with chicken from Abu Hummus and Rahmaneyah were cryptosporidium-free. No correlation overlapping was reported when the prevalence rates of three species were recorded across the same district. The absence of the statistical significance and the correlation between prevalence rates, species examined, and districts of the study is in contrast to previously reported findings (Squire et al., 2017), who found a high correlation between species examined and the district location.

Rates recorded in this study were higher than previously recorded rates of $30.2 \%$ and $14.5 \%$ in the dairy and buffalo calves in Egypt, respectively (Amer et al., 2010 and El-Khodery and Osman, 2008). Older calves have had a higher infection rate than younger calves. Nevertheless, these current rates in the pre-weaned calves still much higher than previously recorded rates in the pre-weaned and post-weaned calves from Egypt (Amer et al., 2010; Amer et al., 2013 and El-Khodery and Osman, 2008). This difference in the prevalence rates between pre-weaned and postweaned calves and between this study and previous ones might have been 
attributed to different health, management, host, and environmental factors (Fayer et al., 2010 and Feng et al., 2012).

Our current data revealed that male calves have had higher prevalence rates than females. This is in contrast to the higher female than male calves recorded respectively (Squire et al., 2017). As also observed in this study, Cryptosporidium was detected in calves with formed, semi formed and watery faecal conditions, indicating that infection with Cryptosporidium could be latent and found in young calves without demonstrating any clinical signs (Fayer et al., 2005 and Wang et al., 2011). Therefore, it is essential to consider the asymptomatic Cryptosporidium infection that may result in reduced feed efficiency rates, decreased weight gain, with the ultimate loss in the dairy industry (Anderson, 1987; Esteban and Anderson, 1995 and Ralston et al., 2003).

In contrast to data of calves, females of human being were presented with a higher prevalence rate, which is similar to previously recorded data from Nigeria (Anejo-Okopi et al., 2016). Similarly, diarrheic human contacts registered a higher detection rate than those with formed and semi-formed, as in contrast to data in calves. These variable findings between calves and human most probably attributed to different species of Cryptosporidium infecting two host species (El Kader et al., 2012 and Helmy et al., 2013).

The overall infection percentage that was recorded in chicken $(6 \%)$ was lower than rates recorded from free-range chickens with cryptosporidium infection in Brazil (25.6\%) and layers flocks in

\section{References}

Amer, S.; Honma, H.; Ikarashi, M.; Tada, C.; Fukuda, Y.; Suyama, Y. and Nakai, Y. (2010): Cryptosporidium genotypes and
Germany (8.3\%) (Ewald et al., 2017 and Helmy et al., 2017). Nevertheless, variation in the detection techniques between our current study (microscopy) and these of Brazil and Germany (PCR and DNA sequencing) might help to understand the variable detection rates. Since no parameters such as age groups, gender, species, and faecal consistencies were recorded in chickens, it become impossible to proceed further with analysis similar to that of calves and human. However, the findings of oocysts of cryptosporidium, and its potential zoonotic transmission to human and other mammals (Bomfim et al., 2013 and Majewska et al., 2009) add to the significance of the current data.

In conclusion, the current data indicated that Cryptosporidium infection is common in calves, and less extent to chickens. The lack of host specificity between mammalian species of Cryptosporidium (calves in this case) could be a potential natural reservoir host and risk of zoonotic transmission for human contacts in the Behera province. Also the presence of infection in the non-diarrheic calves and personnel further consolidated the significance of latent non-symptomatic infection sources for non-infected hosts, and insisted on the importance of routine examination in the endemic areas. From the future prospective, identification of implicated Cryptosporidium species by molecular methods, and examination of the potential evolutionary relatedness which could be inferred from the phylogenetic analysis become increasingly important to gain better understanding of the zoonotic potential of this parasite between mammalian hosts.

subtypes in dairy calves in Egypt. Veterinary parasitology. 169(3-4): 382-386. 
Amer, S.; Zidan, S.; Adamu, H.; Ye, J.; Roellig, D.; Xiao, L. and Feng, Y. (2013): Prevalence and characterization of Cryptosporidium spp. in dairy cattle in Nile River delta provinces, Egypt. Exp Parasitol. 135(3): 518-523.

Anderson, B. (1987): Abomasal cryptosporidiosis in cattle. Veterinary Pathology. 24(3): 235-238.

Anejo-Okopi, J.A.; Okojokwu, J.O.; Ebonyi, A.O.; Ejeliogu, E.U.; Isa, S.E.; Audu, O.; Akpakpan, E.E.; Nwachukwu, E.E.; Ifokwe, C.K. and Ali, M. (2016): Molecular characterization of Cryptosporidium in children aged 0-5 years with diarrhea in Jos, Nigeria. The Pan African Medical Journal. 25(

Baldursson, S. and Karanis, P. (2011): Waterborne transmission of protozoan parasites: review of worldwide outbreaks - an update 2004-2010. Water Res. 45(20): 66036614.

Bomfim, T.; Gomes, R.; Huber, F. and Couto, M. (2013): The importance of poultry in environmental dissemination of Cryptosporidium spp. Open Vet Sci J. 7(1): 12-17.

Chalmers, R.M. and Davies, A.P. (2010): Minireview: clinical cryptosporidiosis. Exp Parasitol. 124(1): 138-146.

Clarke, S.C. and McIntyre, M. (2001): Acid-fast bodies in faecal smears stained by the modified ZiehlNeelsen technique. Br J Biomed Sci. 58(1): 7-10.

El-Khodery, S.A. and Osman, S.A. (2008): Cryptosporidiosis in buffalo calves (Bubalus bubalis): prevalence and potential risk factors. Tropical animal health and production. 40(6): 419-426.

El-Saharty, S.; Richardson, G. and Chase, S. (2005): Egypt and the Millennium Development Goals:
Egypt and the Millennium Development Goals.

El-Seify, M.; Desoukey, M.; Khalafalla, R. and Sorour, S.S. (2012): Prevalence of Eimeria and Cryptosporidium species in cattle in Kafr El-Sheikh Province. Kafrelsheikh Vet Med J. 10(2): 1-22.

El Kader, N.M.A.; Blanco, M.-A.; Ali-Tammam, M.; Abd El Rahman, B.; Osman, A.; El Sheikh, N.; Rubio, J.M. and de Fuentes, I. (2012): Detection of Cryptosporidium parvum and Cryptosporidium hominis in human patients in Cairo, Egypt. Parasitology research. 110(1): 161-166.

Esteban, E. and Anderson, B.C. (1995): Cryptosporidium muris: prevalence, persistency, and detrimental effect on milk production in a drylot dairy. Journal of Dairy Science. 78(5): 1068-1072.

Ewald, M.P.d.C.; Martins, F.D.C.; Caldart, E.T.; Vieira, F.E.G.; Yamamura, M.H.; Sasse, J.P.; Barros, L.D.d.; Freire, R.L.; Navarro, I.T. and Garcia, J.L. (2017): The first study of molecular prevalence and species characterization of Cryptosporidium in free-range chicken (Gallus gallus domesticus) from Brazil. Revista Brasileira de Parasitologia Veterinária. 26(4): 472-478.

Fayer, R. (2010): Taxonomy and species delimitation in Cryptosporidium. Exp Parasitol. 124(1): 90-97.

Fayer, R.; Santin, M. and Dargatz, D. (2010): Species of Cryptosporidium detected in weaned cattle on cow-calf operations in the United States. Vet Parasitol. 170(3-4): 187-192.

Fayer, R.; Santin, M. and Xiao, L. (2005): Cryptosporidium bovis $\mathrm{n}$. $\mathrm{sp}$. (Apicomplexa: Cryptosporidiidae) in cattle (Bos taurus). J Parasitol. 91(3): 624-629. 
Feng, Y.; Karna, S.R.; Dearen, T.K.; Singh, D.K.; Adhikari, L.N.; Shrestha, A. and Xiao, L. (2012): Common occurrence of a unique Cryptosporidium ryanae variant in zebu cattle and water buffaloes in the buffer zone of the Chitwan National Park, Nepal. Vet Parasitol. 185(2-4): 309-314.

Feng, Y.; Ortega, Y.; He, G.; Das, P.; Xu, M.; Zhang, X.; Fayer, R.; Gatei, W.; Cama, V. and Xiao, L. (2007): Wide geographic distribution of Cryptosporidium bovis and the deer-like genotype in bovines. Vet Parasitol. 144(1-2): 1-9.

Ghoneim, N.H.; Hassanain, M.A.; Hamza, D.A.; Shaapan, R.M. and Draz, S.H. (2017): Prevalence and molecular epidemiology of Cryptosporidium infection in calves and hospitalized children in Egypt. Res. J. Parasitol. 12(19-26.

Helmy, Y.A.; Krücken, J.; Abdelwhab, E.-S.M.; von SamsonHimmelstjerna, G. and Hafez, H.M. (2017): Molecular diagnosis and characterization of Cryptosporidium spp. in turkeys and chickens in Germany reveals evidence for previously undetected parasite species. PloS one. 12(6): e0177150.

Helmy, Y.A.; Krücken, J.; Nöckler, K.; von Samson-Himmelstjerna, G. and Zessin, K.-H. (2013): Molecular epidemiology of Cryptosporidium in livestock animals and humans in the Ismailia province of Egypt. Veterinary parasitology. 193(1-3): 15-24.

Karanis, P.; Kourenti, C. and Smith, H. (2007a): Waterborne transmission of protozoan parasites: a worldwide review of outbreaks and lessons learnt. J Water Health. 5(1): 1-38.

Karanis, P.; Plutzer, J.; Halim, N.A.; Igori, K.; Nagasawa, H.; Ongerth, $J$. and Liqing, M. (2007b): Molecular characterization of
Cryptosporidium from animal sources in Qinghai province of China. Parasitol Res. 101(6): 15751580.

Khurana, S. and Chaudhary, $P$. (2018): Laboratory diagnosis of cryptosporidiosis. Trop Parasitol. 8(1): 2-7.

Kotloff, K.L.; Nataro, J.P.; Blackwelder, W.C.; Nasrin, D.; Farag, T.H.; Panchalingam, S.; Wu, Y.; Sow, S.O.; Sur, D.; Breiman, R.F.; Faruque, A.S.; Zaidi, A.K.; Saha, D.; Alonso, P.L.; Tamboura, B.; Sanogo, D.; Onwuchekwa, U.; Manna, B.; Ramamurthy, T.; Kanungo, S.; Ochieng, J.B.; Omore, R.; Oundo, J.O.; Hossain, A.; Das, S.K.; Ahmed, S.; Qureshi, S.; Quadri, F.; Adegbola, R.A.; Antonio, M.; Hossain, M.J.; Akinsola, A.; Mandomando, I.; Nhampossa, T.; Acacio, S.; Biswas, K.; O'Reilly, C.E.; Mintz, E.D.; Berkeley, L.Y.; Muhsen, K.; Sommerfelt, H.; Robins-Browne, R.M. and Levine, M.M. (2013): Burden and aetiology of diarrhoeal disease in infants and young children in developing countries (the Global Enteric Multicenter Study, GEMS): a prospective, case-control study. Lancet. 382(9888): 209-222.

Ma, L.; Sotiriadou, I.; Cai, Q.; Karanis, G.; Wang, G.; Wang, G.; Lu, Y.; Li, X. and Karanis, P. (2014): Detection of Cryptosporidium and Giardia in agricultural and water environments in the Qinghai area of China by IFT and PCR. Parasitol Res. 113(9): 3177-3184.

Ma, P. and Soave, R. (1983): Threestep stool examination for cryptosporidiosis in 10 homosexual men with protracted watery diarrhea. J Infect Dis. 147(5): 824-828.

Majewska, A.C.; Graczyk, T.K.; Słodkowicz-Kowalska,

A.; 
Tamang, L.; Jędrzejewski， S.; Zduniak, P.; Solarczyk, P.; Nowosad, A. and Nowosad, $P$. (2009): The role of free-ranging, captive, and domestic birds of Western Poland in environmental contamination with Cryptosporidium parvum oocysts and Giardia lamblia cysts. Parasitology Research. 104(5): 1093-1099.

OIE (2008): Cryptosporidiosis. In: Terrestrial manual chapter 2.9.4, pp 1192-1215.

Plutzer, J. and Karanis, P. (2009): Genetic polymorphism in Cryptosporidium species: an update. Vet Parasitol. 165(3-4): 187-199.

Ralston, B.; Cockwill, C.; Guselle, N.; Van Herk, F.; McAllister, T. and Olson, M. (2003): Prevalence of Giardia and Cryptosporidium andersoni and their effects on performance in feedlot beef cattle. Canadian journal of animal science. 83(1): 153-159.

Ryan, U.; Fayer, R. and Xiao, L. (2014): Cryptosporidium species in humans and animals: current understanding and research needs. Parasitology. 141(13): 1667-1685.

Shaaban, S.I.; Ayoub, M.A.; Ghorbal, S.H.M. and Nossair, M.A. (2018): Calves as a Reservoir of Some Diarrheagenic Agents for Human Contacts in El-Behira Province. Alexandria Journal of Veterinary Sciences. 56(2): 48-53.
Squire, S.A.; Yang, R.; Robertson, I.; Ayi, I. and Ryan, U. (2017): Molecular characterization of Cryptosporidium and Giardia in farmers and their ruminant livestock from the Coastal Savannah zone of Ghana. Infect Genet Evol. 55(236243.

Striepen, B. (2013): Parasitic infections: Time to tackle cryptosporidiosis. Nature. 503(7475): 189-191.

Wang, R.; Ma, G.; Zhao, J.; Lu, Q.; Wang, H.; Zhang, L.; Jian, F.; Ning, C. and Xiao, L. (2011): Cryptosporidium andersoni is the predominant species in post-weaned and adult dairy cattle in China. Parasitol Int. 60(1): 1-4.

Wumba, R.D.; Zanga, J.; Mbanzulu, K.M.; Mandina, M.N.; Kahindo, A.K.; Aloni, M.N. and Ekila, M.B. (2015): Cryptosporidium identification in HIV-Infected Humans. Experience from Kinshasa, the Democratic Republic of Congo. Acta Parasitol. 60(4): 638-644.

Xiao, L. (2010): Molecular epidemiology of cryptosporidiosis: an update. Exp Parasitol. 124(1): 8089.

Zhang, W.; Wang, R.; Yang, F.; Zhang, L.; Cao, J.; Zhang, X.; Ling, H.; Liu, A. and Shen, Y. (2013): Distribution and genetic characterizations of Cryptosporidium spp. in pre-weaned dairy calves in Northeastern China's Heilongjiang Province. PLoS One. 8(1): e54857. 
الملخص المعبي

الاتثشار الطفيلي للعدوي بالكريبتوسبوريديوم في العجول والاجاج والانسان في محافظة البحيرة

$$
\begin{aligned}
& \text { محمد بساط" , هيثم العادلي ', و نادية لبن' }
\end{aligned}
$$

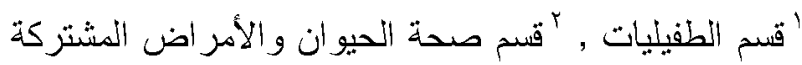

$$
\begin{aligned}
& \text { كليه الطب البيطرى - جامعه الإسكندريه } \\
& \text { أبيس · (ا، الإسكندريه } \\
& \text { الزمز البريدى:؟ ؛ } 19
\end{aligned}
$$

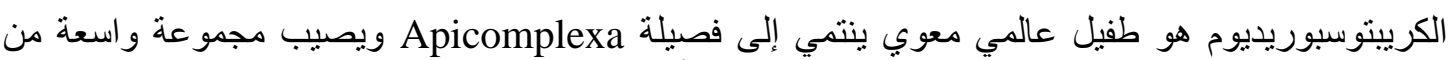

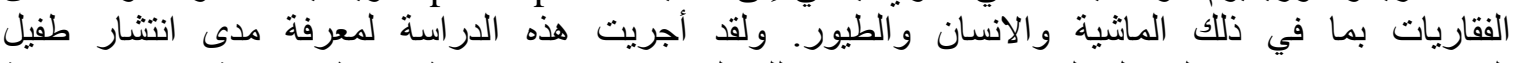

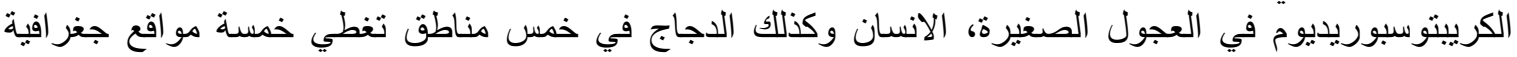

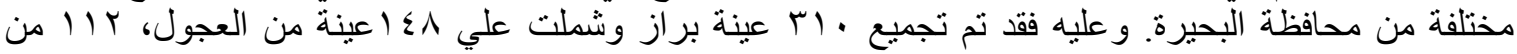

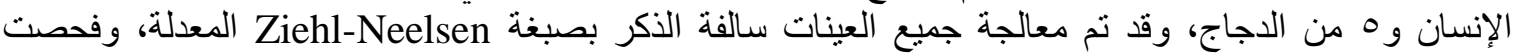

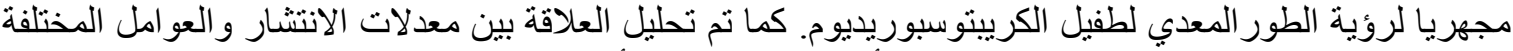

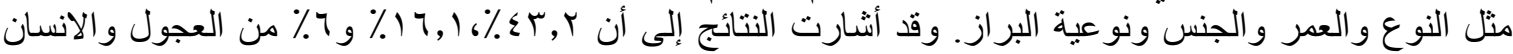

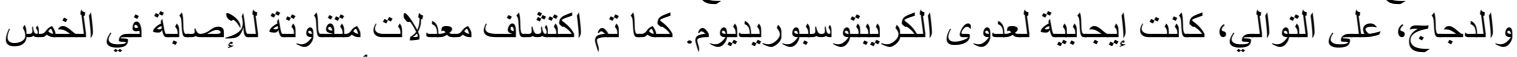

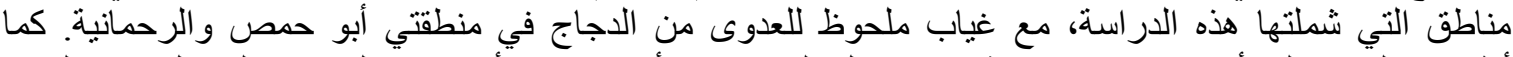

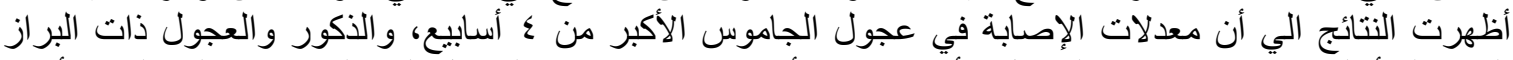

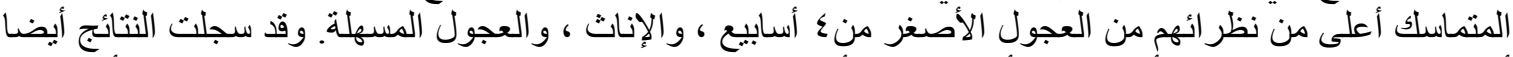

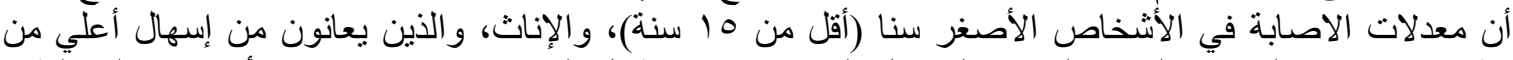

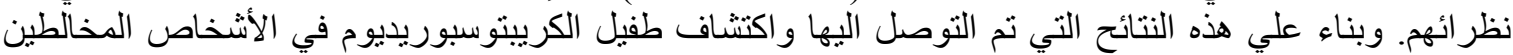

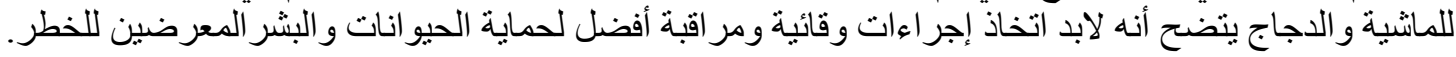

